\title{
Microcontainer Delivery of Antibiotic Improves Treatment of Pseudomonas aeruginosa
} Biofilms

Birk, Stine Egebro; Haagensen, Janus Anders Juul; Johansen, Helle Krogh; Molin, Søren; Nielsen, Line Hagner; Boisen, Anja

Published in:

Advanced Healthcare Materials

Link to article, DOI:

10.1002/adhm.201901779

Publication date:

2020

Document Version

Peer reviewed version

Link back to DTU Orbit

Citation $(A P A)$ :

Birk, S. E., Haagensen, J. A. J., Johansen, H. K., Molin, S., Nielsen, L. H., \& Boisen, A. (2020). Microcontainer Delivery of Antibiotic Improves Treatment of Pseudomonas aeruginosa Biofilms. Advanced Healthcare Materials, 9(10), [e1901779]. https://doi.org/10.1002/adhm.201901779

\section{General rights}

Copyright and moral rights for the publications made accessible in the public portal are retained by the authors and/or other copyright owners and it is a condition of accessing publications that users recognise and abide by the legal requirements associated with these rights.

- Users may download and print one copy of any publication from the public portal for the purpose of private study or research.

- You may not further distribute the material or use it for any profit-making activity or commercial gain

- You may freely distribute the URL identifying the publication in the public portal 


\section{Microcontainer Delivery of Antibiotic Improves Treatment of}

\section{Pseudomonas aeruginosa Biofilms}

3 Stine Egebro Birk*, Janus Anders Juul Haagensen, Helle Krogh Johansen, Søren Molin, Line Hagner

$4 \quad$ Nielsen and Anja Boisen

5

6 M.Sc. S. E. B., Dr. L. H. N. and Prof. A. B.

7 The Danish National Research Foundation and Villum Foundation's Center for Intelligent Drug

8 Delivery and Sensing Using Microcontainers and Nanomechanics (IDUN), Department of Health

9 Technology, Technical University of Denmark, Kgs. Lyngby, Denmark.

10 *Corresponding author

11 Stine Egebro Birk

12 Ørsteds Plads 345C

132800 Lyngby

14 stegha@dtu.dk

$15+4545255773$

16

17 Dr. J. A. J. H., Prof. S. M.

18 Novo Nordisk Foundation Center for Biosustainability, Technical University of Denmark, Kgs.

19 Lyngby, Denmark

20

21 Prof. H. K. J.

22 Department of Clinical Microbiology, 9301, Rigshospitalet, Copenhagen, Denmark and Department

23 of Clinical Medicine, Faculty of Health and Medical Sciences, University of Copenhagen,

24 Copenhagen, Denmark

25 Keywords 


\section{WILEY-VCH}

26 Bacterial biofilm, microdevices, drug delivery, polymeric coatings, ciprofloxacin

$28 \underline{\text { Abstract }}$

29 Biofilm-associated infections are difficult to treat effectively with antibiotics despite repeated

30 treatments. Polymeric microdevices (microcontainers) have previously been shown to engulf in

31 mucus layers and to provide tunable release. Such devices may overcome the challenge of delivering 32 antibiotics into the biofilm, increasing the local drug concentration and hence improve local bacterial

33 killing. In this work, microcontainers are loaded with the antibiotic, ciprofloxacin hydrochloride, and

34 functionalized with polymeric lids of polyethylene glycol (PEG), chitosan or Eudragit ${ }^{\circledR}$ S100. The 35 PEG lid gives rise to a drug release comparable to uncoated microcontainers showing complete 36 release after $8 \mathrm{~h}$, whereas Chitosan and Eudragit ${ }^{\circledR} \mathrm{S} 100$ lids result in continuous release during the course of $24 \mathrm{~h}$. All antibiotic-containing microcontainers inhibit planktonic growth of Pseudomonas aeruginosa (PAO1) cells, but the degree of inhibition depends on the coating. Microcontainers with ciprofloxacin hydrochloride kill about three times more biofilm-associated PAO1 cells compared with a single standard bolus. Moreover, the use of microcontainers in biofilm result in bacterial killing

41 equal to a constant flow of a three times higher concentration of solubilized antibiotics. These studies suggest that microcontainers can be useful for antibiotic delivery in treatment of biofilm-associated infections, resulting in more effective treatment and reduced use of antibiotics. 


\section{WILEY-VCH}

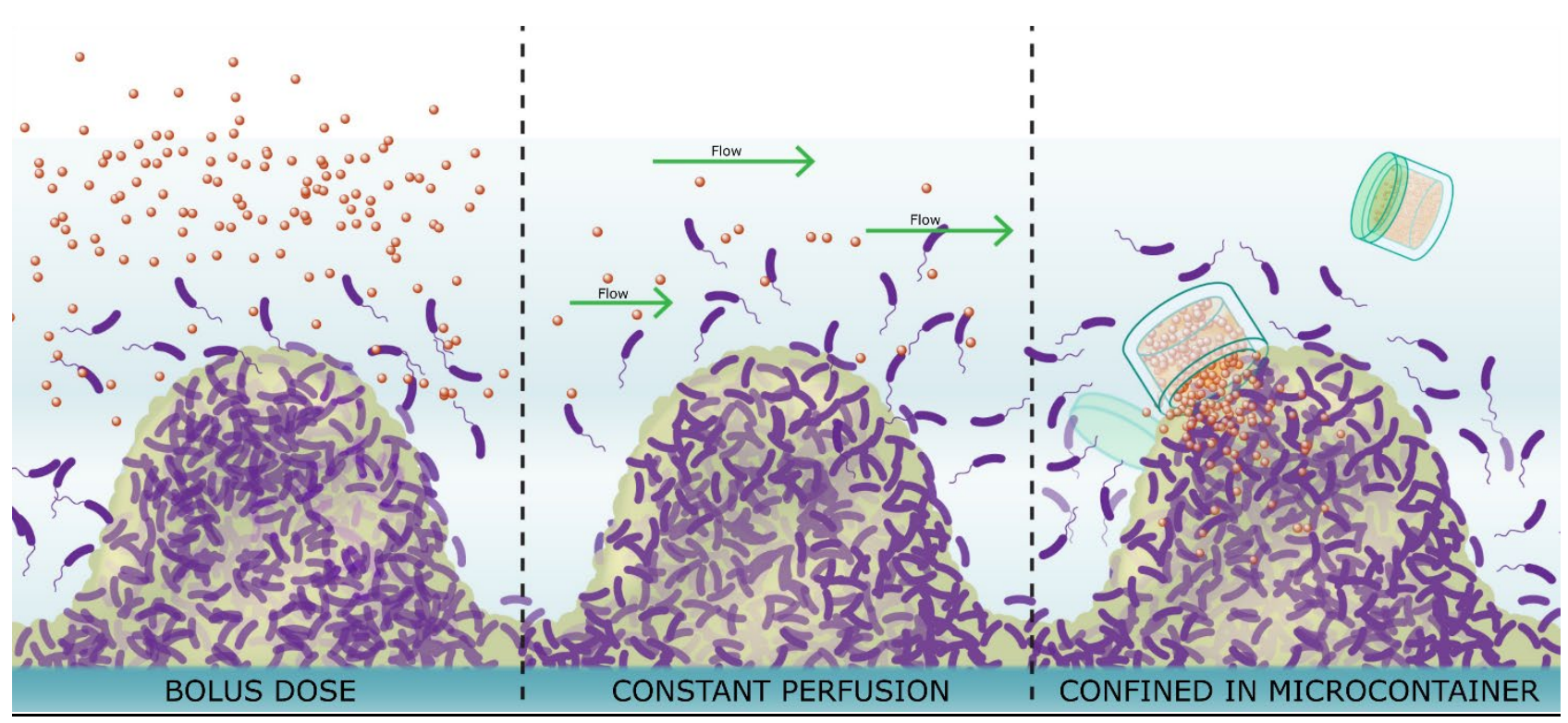

\section{Introduction}

327 A biofilm is a consortium of bacteria living together in a self-produced extracellular polymeric 328 substances (EPS) matrix consisting of various polysaccharides, proteins and DNA. ${ }^{[1,2]}$ The bacteria 329 adhere to each other and to surfaces, aggregates develop, and the biofilm promotes bacterial survival 330 in otherwise hostile environments. ${ }^{[3,4]}$ Biofilm-associated infections are difficult to treat, and they are 331 often associated with chronic infections, resulting in recurrent inflammation and exacerbations 332 despite intense treatment with antibiotics. In contrast, bacteria living as planktonic, single-cell 333 populations in suspension show decreased tolerance towards antibiotics, and hence are easier to treat. ${ }^{[1,2,5]}$

Pseudomonas aeruginosa is a Gram-negative pathogenic bacterial species forming biofilms and causing devastating chronic infections in immuno-compromised individuals. ${ }^{[3,6]} P$. aeruginosa can cause serious intestinal infections, where it for example has been isolated from patients suffering from

338 inflammatory bowel disease and cancer patients. ${ }^{[7,8]}$ The gastrointestinal tract is often considered to

339 be an important reservoir for $P$. aeruginosa and the presence in the intestines is responsible for 340 increased mortality in gut-derived sepsis and bacteremia and facilitates hematogenous spread of 


\section{WILEY-VCH}

341 infections to other organs. ${ }^{[8]} P$. aeruginosa often causes chronic lung infections in patients suffering

342 from cystic fibrosis due to the accumulation of thick, sticky mucus and to the consequentially 343 impaired mucociliary clearance. ${ }^{[4,5]}$

344 Antibiotic treatment is the standard therapy for chronic infections with $P$. aeruginosa, but it is difficult 345 to fully combat $P$. aeruginosa infections. ${ }^{[9]}$ One of the most often used antibiotics is ciprofloxacin.

346 This is a broad spectrum second generation fluoroquinolone with a reported low frequency of spontaneous bacterial resistance. ${ }^{[10,11]}$ Delivery of several antibiotics to biofilm-associated infections is, however, obstructed by the EPS matrix. This viscous structure creates diffusional barriers that may deactivate the antibiotics in the outer layers of the biofilm faster than they diffuse, leading to insufficient antimicrobial effects. ${ }^{[4,12,13]}$ Also, the EPS allows development of phenotypically

351 different subpopulations with reduced metabolic activities and growth properties, making the bacteria more tolerant to antibiotic treatment. ${ }^{[2]}$

353 Standard delivery of antibiotics is usually untargeted, and will result in distribution of the drugs to all parts of the body. Consequently, the efficacy of the antibiotics may decrease, since reduced concentrations of the antibiotics may reach the actual site of the infection. ${ }^{[14]}$ The recalcitrance of infectious biofilms towards antibiotics may be overcome by the use of a local antibiotic delivery system creating a high local concentration, and hence a more effective treatment. In recent years, nanotechnology-based drug delivery systems such as mesoporous silica nanoparticles, polymeric nanoparticles and liposomes have been broadly studied as antibiotic carriers facilitating penetration 360 and ultimately killing of infectious biofilms. ${ }^{[13]}$ However, many of these formulations suffer from 361 poor storage stability ${ }^{[13]}$, versatility may be limited and usage depends on the properties of the active 362 pharmaceutical drug i.e. charge, size and hydrophilicity. Microfabricated drug delivery devices have 363 shown promise towards increasing local drug concentration ${ }^{[15,16]}$, and might as well be a suitable 364 system for delivering antibiotics to specific sites of infection. One of such devices is a microcontainer, 365 which is a micrometer sized polymeric device mainly developed for oral delivery of therapeutics. ${ }^{[17]}$ 


\section{WILEY-VCH}

366 Microcontainers have proven to be able to improve oral bioavailability of small drugs, most likely

367 due to the fact that microcontainers have mucoadhesive properties and are engulfed within the 368 intestinal mucus. ${ }^{[18,19]}$ In addition, microcontainers have the benefit of being very versatile and can 369 be used for delivery of any active pharmaceutical ingredient no matter size, charge or hydrophilicity. 370 The microcontainers can be functionalized by applying a polymeric lid onto the cavity of drug-loaded 371 microcontainers. ${ }^{[20]}$ Polymers with different properties can be used to e.g. control the drug release 372 profiles, to achieve additional mucoadhesive or mucus penetrating effects, and/or to provide 373 additional antibacterial activity. Polyethylene glycol (PEG) is an uncharged hydrophilic polymer that 374 has been shown to possess either mucoadhesive or mucus penetrating properties, depending on the 375 surface density and the molecular weight. ${ }^{[21,22]}$ Wang et al. documented improved mucus penetration 376 of polystyrene nanoparticles coated with low molecular weight (MW) PEG, whereas higher MW PEG 377 improved mucoadhesion. ${ }^{[23]}$ Chitosan is a cationic polysaccharide that has been widely explored as a 378 mucoadhesive polymer. In addition, it provides controlled drug release, prolonging the therapeutic 379 effect of the drug ${ }^{[24,25]}$, and has also been reported to possess antimicrobial properties. ${ }^{[26]}$ Previously, 380 the inhibitory effect of chitosan solutions and nanoparticles without antibiotics against $P$. aeruginosa 381 clinical isolates in planktonic and biofilm conditions was investigated, and it was shown that 382 planktonic bacteria were more effectively eradicated than biofilm-associated bacteria. ${ }^{[27]}$ Eudragit $^{\circledR}$ $383 \mathrm{~S} 100$ is an anionic co-polymer widely used for $\mathrm{pH}$-responsive formulations as it dissolves at $\mathrm{pH}$ 384 values above $7 .^{[28,29]}$ It has previously been reported that using Eudragit microparticles for antibiotic 385 delivery caused a significant reduction in adherent methicillin-resistant Staphylococcus aureus 386 compared to treatment with free antibiotics. ${ }^{[30]}$

387 The aim of this study is to investigate the potential impact of using microcontainers in the treatment 388 of $P$. aeruginosa biofilms. The microcontainers are suggested to adhere to the biofilm and release the 389 loaded ciprofloxacin in a controlled and localized manner. Ciprofloxacin-loaded microcontainers 390 were coated with polymeric lids of PEG, chitosan and Eudragit ${ }^{\circledR}$ S100. Together with investigating 


\section{WILEY-VCH}

391 the drug release, the resulting antimicrobial activity obtained from the functionalized microcontainers were tested on planktonic bacterial cells as well as on biofilm consortia of P. aeruginosa and compared to delivery of unconfined antibiotic.

\section{Results \& Discussion}

\subsection{Loading of antibiotic into microcontainers and lid depositing}

Microcontainers (Figure 1A and Sup. Info, Figure S1) with an inner diameter of $232 \pm 1 \mu \mathrm{m}$ and an inner height of $214 \pm 3 \mu \mathrm{m}$ (mean $\pm \mathrm{SD}, \mathrm{n}=3$ ) were produced and successfully loaded with $2.75 \pm 0.48$ mg ( $\mathrm{n}=44$ chips, mean \pm SD) ciprofloxacin hydrochloride (CIP) per chip corresponding to $4.39 \pm 0.77$ $\mu \mathrm{g}$ in each microcontainer. The loaded microcontainers were visualized using scanning electron microscopy (SEM), which confirmed efficient loading (Figure 1B). Following the drug loading, the microcontainers were coated on the cavity with either PEG, chitosan or Eudragit ${ }^{\circledR}$ S100, and the height and morphology of the spray coated lids were characterized by profilometry and SEM. Coating with PEG resulted in a uniform lid (Figure 1C), which was also confirmed by profilometry measurements revealing a low surface roughness and a coating thickness of $32.4 \pm 1.9 \mu \mathrm{m}$ (mean $\pm \mathrm{SD}$, $\mathrm{n}=3$ ). Mazzoni et al. reported a coating thickness of $17.0 \pm 5.6 \mu \mathrm{m}$ when coating microcontainers using $0.7 \% \mathrm{w} / \mathrm{v}$ PEG dissolved in dichloromethane. ${ }^{[20]}$ In this study, $2.66 \% \mathrm{w} / \mathrm{v}$ of PEG has been utilized with water as solvent, and it was observed that these changes increased the coating thickness with a

408 factor two. The chitosan coating (Figure 1D) resulted in the thinnest lid among the three polymers, 409 since the polymer concentration was lower and the spray coating parameters different. The chitosan 410 lid did not cover the open cavity of the microcontainer completely, and structures of the CIP crystals 411 were still visible. However, we aimed for a thin layer as chitosan is hygroscopic and quickly swells 412 when in contact with water, hence creating a hydrogel lid affecting the release of CIP. ${ }^{[31,32]}$ The 413 thickness of the chitosan coating was $8.9 \pm 0.7 \mu \mathrm{m}($ mean $\pm \mathrm{SD}, \mathrm{n}=6)$, in accordance with previously 414 reported heights. ${ }^{[20]}$ Eudragit $^{\circledR}$ S100 coating was shown to cover the entire opening of the 


\section{WILEY-VCH}

415 microcontainer and to be homogenously distributed (Figure 1E), and the height was $25.0 \pm 5.3 \mu \mathrm{m}$

$416 \quad($ mean $\pm \mathrm{SD}, \mathrm{n}=6)$.
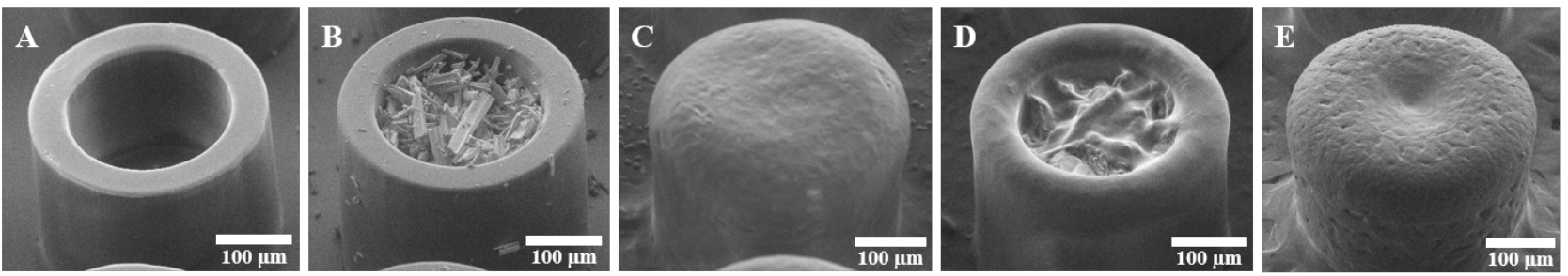

Figure 1. Scanning electron microscopy (SEM) images of a microcontainer (A) empty, (B) loaded with ciprofloxacin hydrochloride (CIP), (C) coated with polyethylene glycol (PEG), (D) coated with chitosan and (E) coated with Eudragit ${ }^{\mathbb{B}}$ S100.

\subsection{In vitro release of ciprofloxacin hydrochloride from microcontainers}

The release of CIP from uncoated and coated microcontainers was evaluated in a modified minimal medium, FAB medium ${ }^{[33]}$. When no coating was applied onto the microcontainers, it appears that two types of release kinetics apply. Within the first min an initial burst release of $42.1 \pm 4.5 \%$ of CIP occurred, followed by 7 h sustained release before reaching a plateau (Figure 2A). Applying a PEG lid on the microcontainers resulted in a lower initial release $(31.5 \pm 1.9 \%$ CIP released from PEGcoated microcontainers after 10 min compared to $44.7 \pm 4.9 \%$ CIP released from uncoated microcontainers). However, after 90 min no significant differences in the release profiles were observed (Figure 2A). This is consistent with PEG being a water-soluble polymer ${ }^{[34]}$, which quickly solubilizes in the aqueous FAB medium. Chitosan coating gave rise to an initial release of $25.9 \pm 5.6$ \% CIP after 90 min, followed by a subsequent sustained release with $99.5 \pm 9.1 \%$ being released after $28 \mathrm{~h}$ (Figure 2B). In accordance, it has previously been shown that chitosan nanoparticles also provide a burst release of CIP followed by a sustained release behavior. ${ }^{[35]}$ SEM images confirmed swelling and after $28 \mathrm{~h}$ the hydrogel was still present on the microcontainers (data not shown), presumably due to the limited solubility of chitosan at physiological $\mathrm{pH}^{[32]}$ The sustained release profiles are likely caused by a slow but constant diffusion of entrapped CIP trough the chitosan hydrogel. Eudragit ${ }^{\circledR}$ S100 was included as a coating to provide protection of CIP until the microcontainers had reached the biofilm growing bacteria in the flow cell system, and fast release 


\section{WILEY-VCH}

438 could be induced by increasing the $\mathrm{pH}$ of the FAB medium. As can be seen from Figure 2C, the 439 coating was kept intact for up to $15 \mathrm{~min}$, and release was triggered when increasing the $\mathrm{pH}$ from 6.8 440 to 7.4. This is in accordance with Eudragit ${ }^{\circledR} \mathrm{S} 100$ being solubilized at $\mathrm{pH}$ values above $7 .{ }^{[29]}$ To 441 facilitate inoculation of the microcontainers into a flow cell system, they were shortly embedded in a 442 gelatin hydrogel at $\mathrm{pH}$ 6.8. The release data support that the lid was kept intact during the time in the 443 hydrogel, and that release was triggered in the growth medium with a $\mathrm{pH}$ of 7.4. However, the release 444 of CIP from Eudragit ${ }^{\circledR}$ S100-coated microcontainers was sustained, with only $46.1 \pm 3.0 \%$ being 445 released after $4 \mathrm{~h}$ and $90.2 \pm 2.8 \%$ after $18 \mathrm{~h}$. This complies with previous findings in the literature, 446 observing that albumin-containing microspheres coated with Eudragit ${ }^{\circledR}$ S100 showed a sustained 447 release in intestinal $\mathrm{pH}$ reaching complete release after 16 h. ${ }^{[36]}$ 
A

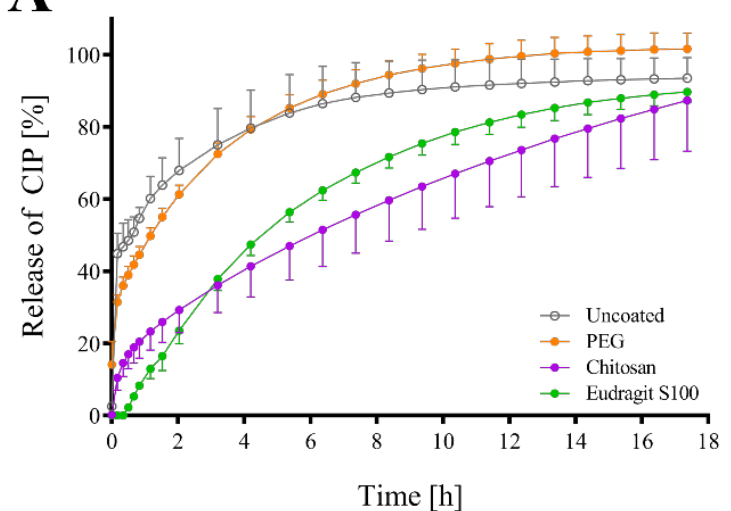

B

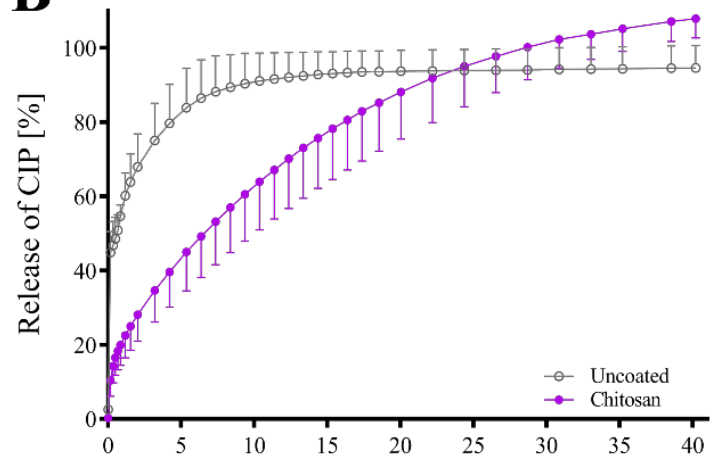

C

Time [h]

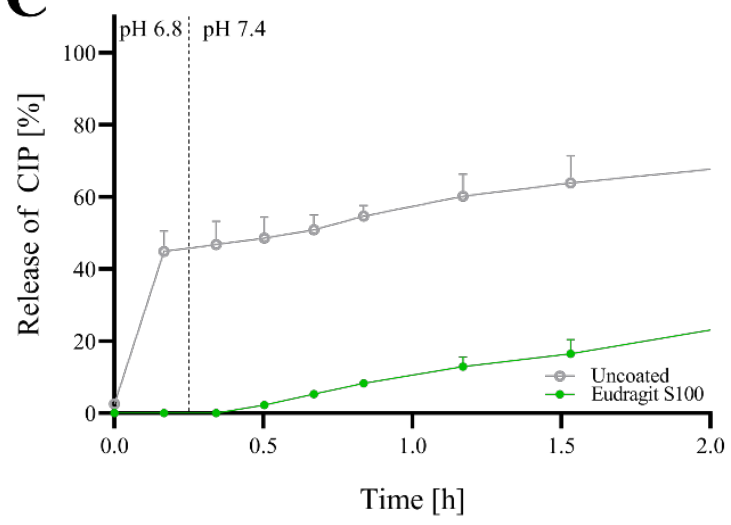



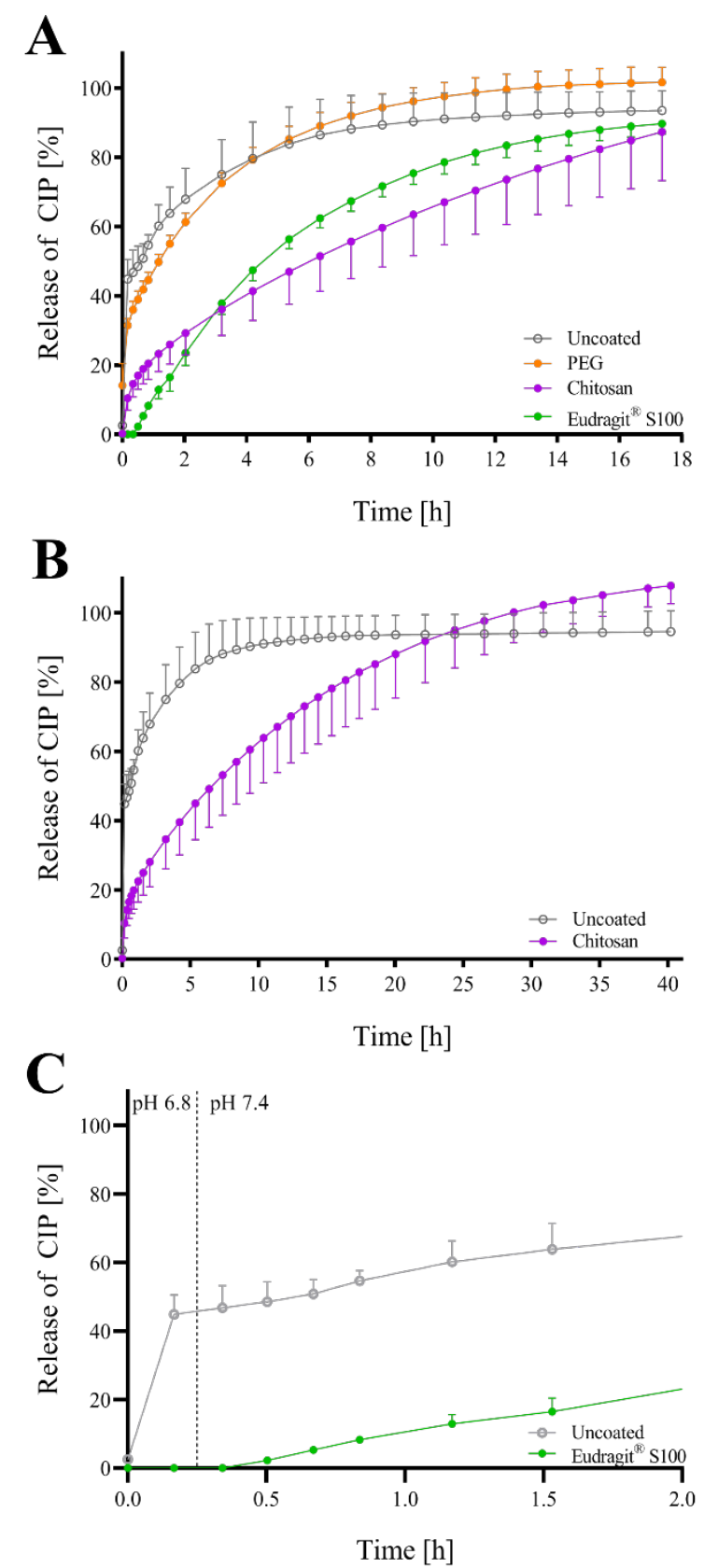

Figure 2. In vitro cumulative release of ciprofloxacin hydrochloride (CIP) from microcontainers in FAB medium as a function of time. A) Uncoated microcontainers compared to microcontainers coated with polyethylene glycol (PEG), chitosan or Eudragit ${ }^{\mathbb{R}} \mathrm{S} 100$. Release differed significantly from uncoated microcontainers until $\mathrm{t}=90 \mathrm{~min}(\mathrm{PEG}), \mathrm{t}=11 \mathrm{~h}$ (Eudragit $\left.{ }^{\mathbb{B}} \mathrm{S} 100\right)$ and $\mathrm{t}=13 \mathrm{~h}(\mathrm{chitosan})$. B) Zoom-out depicting the release of CIP during $40 \mathrm{~h}$ with chitosan coating. C) Magnified view showing the initial release of CIP with Eudragit ${ }^{\circledR}$ S100 coating. In experiments with Eudragit ${ }^{\circledR}$ S100 the chips were placed in FAB medium at pH 6.8 for 15 min followed by immersion in FAB medium at $\mathrm{pH}$ 7.4. Data are presented as mean $\pm \mathrm{SD}(\mathrm{n}=3-6)$ and an unpaired t-test was applied for determination of significant difference (with statistical significance defined as $\mathrm{p}<0.05$ ).

\subsection{Impact of microcontainers on planktonic growth of PAO1 cells}

459 The impacts of empty, CIP-loaded and polymer-coated microcontainers on bacterial growth 460 inhibition were determined from addition of these to planktonic PAO1 cultures. Bacterial growth 461 inhibition observed for CIP-loaded uncoated and PEG-coated microcontainers, respectively, differed 


\section{WILEY-VCH}

462 significantly after $3 \mathrm{~h}$ from the PAO1 control growth (p-value $\leq 0.0017$ ), whereas CIP mediated 463 bacterial growth inhibition with chitosan and Eudragit ${ }^{\circledR}$ S100, respectively, differed significantly 464 from control after $4 \mathrm{~h}(\mathrm{p}$-values $\leq 0.0013)$ (Figure 3A). These results align with the release data (cf. 465 Figure 2), in which only limited differences in release profiles were observed for uncoated and PEG466 coated microcontainers, whereas delayed releases of CIP were observed for both chitosan and 467 Eudragit $^{\circledR}$ S100. Addition of all loaded and polymer-coated microcontainers led to reductions in 468 viable counts of PAO1, reaching the lowest bacterial viability after $8 \mathrm{~h}$ of treatment with viable counts 469 reduced from app. $10^{9}$ colony forming units (CFU) $\mathrm{mL}^{-1}$ (control) to between $10^{4}-10^{6} \mathrm{CFU} \mathrm{mL}^{-1}$ 470 (Figure 3B). The increase of $\mathrm{OD}_{600}$ during the first $3 \mathrm{~h}$ after addition of the microcontainers seemingly 471 conflicts with the decrease in CFU during this period. We suggest that this 'conflict' is a reflection 472 of a reduced plating efficiency of the treated bacteria, which shows that although the antibiotic exerts 473 its inhibitory effect of reducing viability of the bacteria, it takes time to stop increase of the optical 474 density. This increase most likely reflects that the cells may continue to grow in size without dividing 475 and quickly loose the capacity to form colonies on plates. The delayed cell lysis is observed later as 476 a decrease in $\mathrm{OD}_{600}$. After $24 \mathrm{~h}$, re-growth of viable cells was observed in all treated cultures, reaching 477 an average of $1.73 \times 10^{8} \mathrm{CFU} \mathrm{mL}^{-1}$ (Figure 3B). Regrowth may be due to a subpopulation of resistant 478 cells not affected by the applied CIP concentrations. The empty microcontainers had no effect on 479 growth of PAO1 cells (Figure 3A and B). Treating the planktonic bacterial suspension with $20 \mu \mathrm{L}$ 480 of a $0.22 \mathrm{mg} / \mathrm{ml} \mathrm{CIP}$ solution (same amount as confined in one microcontainer) resulted in identical 481 growth inhibition (Figure 3A and B), proving that administration of CIP in microcontainers did not 482 decrease the efficacy of the antibiotic towards planktonic suspensions of PAO1. 

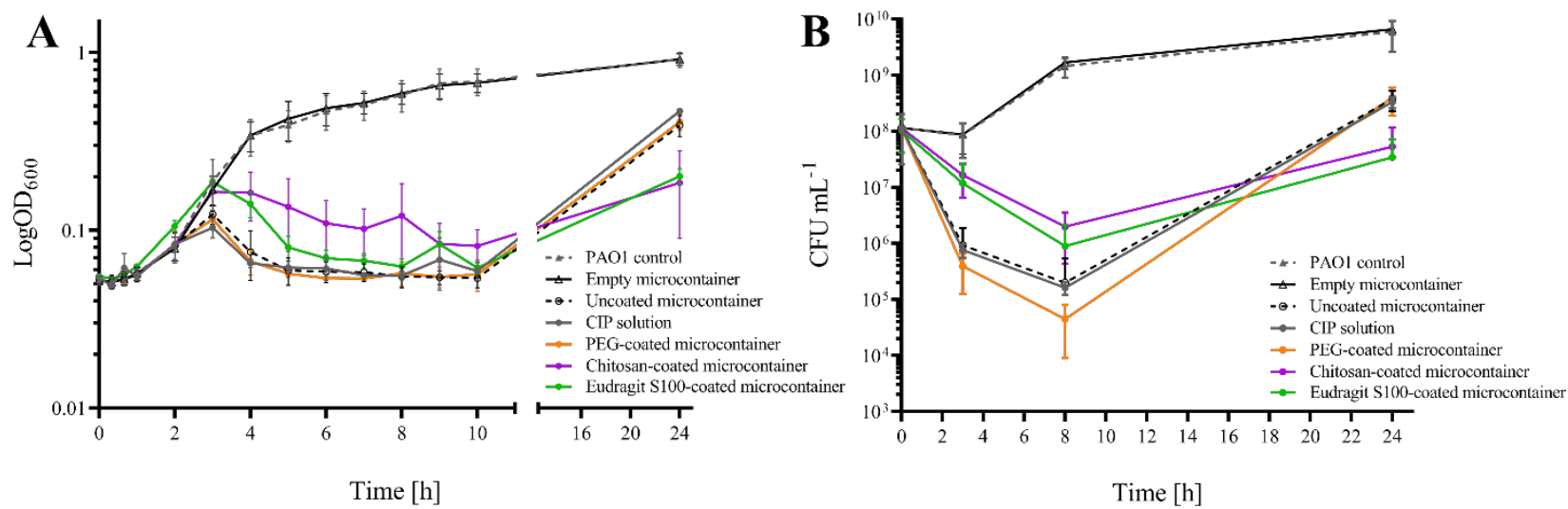

Figure 3. Impact of the microcontainers on planktonic growth inhibition of PAO1 cells. A) Measurement of the optical density $\left(\log \mathrm{OD}_{600}\right)$ as a function of time. Significant difference after $\mathrm{t}=3 \mathrm{~h}$ (CIP solution; uncoated; PEG) and $\mathrm{t}=4 \mathrm{~h}$ (chitosan, Eudragit ${ }^{\circledR}$ $\mathrm{S} 100$ ) when compared to PAO1 control growth. B) Viable counts measured as CFU mL $\mathrm{m}^{-1}$ as a function of time. Color codes represent microcontainers loaded with ciprofloxacin hydrochloride (CIP) and coated with polyethylene glycol (PEG), chitosan or Eudragit ${ }^{\circledR}$ S100. Controls include PAO1 growth control without microcontainer addition, empty microcontainers, uncoated microcontainers as well as CIP in solution. Data are depicted as mean $\pm \mathrm{SD}(\mathrm{n}=3-4)$ and one-way ANOVA with Tukey's multiple comparison was applied for determination of significant difference (with statistical significance defined as $p<0.05$ ).

\subsection{Impact of microcontainers on biofilm growth of PAO1 cells}

493 Antibiotics, which normally inhibit growth and kill bacteria in suspended cultures, have been shown to be much less efficient in bacterial biofilms. ${ }^{[1]}$ This specific behavior of biofilm bacteria is a serious medical problem, since many infections are characterized by biofilm growth in the human body. Microcontainers potentially may deliver a large dose of antibiotics into close contact with a localized infection, increasing the local concentration of antibiotics, which may improve the chance of eradicating the bacteria in the biofilm. Controlling the release rate by the use of different coatings makes it possible to expose the biofilm to specific concentrations of CIP over time. PAO1 biofilms were allowed to mature for $96 \mathrm{~h}$ in flow cell chambers, reaching a biomass of $5.35 \pm 3.74 \mu \mathrm{m}^{3} \mu \mathrm{m}^{-2}$ (Sup. Info, Figure S2). Subsequently, microcontainers were successfully introduced into the flow cell biofilm. A bright field image of the top of a PEG-coated microcontainer together with a corresponding confocal scanning laser microscopy (CSLM) image is shown in Figure 4. 


\section{WILEY-VCH}

BF

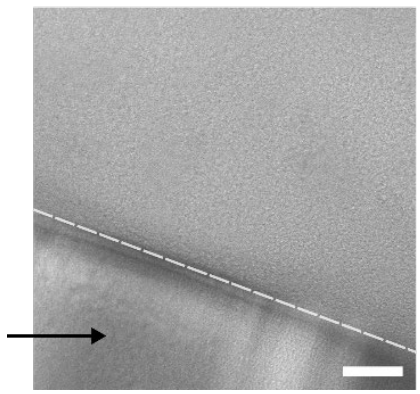

\section{CLSM}

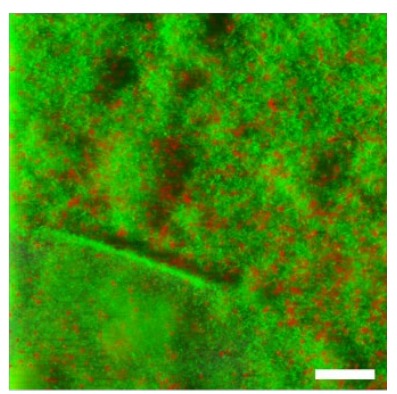

Figure 4. Example of a bright field (BF) image of a microcontainer (located below the dotted line and marked with an arrow) and the corresponding confocal scanning laser microscopy (CSLM) image of a $96 \mathrm{~h}$ old biofilm after $7 \mathrm{~h}$ of treatment with CIP-loaded and polyethylene glycol (PEG)-coated microcontainers. Green represents live GFP fluorescent bacteria. Red represents dead bacteria after PI staining. Scale bar: $30 \mu \mathrm{m}$.

509 To determine efficacies of PEG-, chitosan- or Eudragit ${ }^{\circledR}$ S100-coated microcontainers on killing of

510 biofilm-associated PAO1 cells, confocal images were acquired at locations in close proximity to the

511 microcontainers (Figure 5).

A

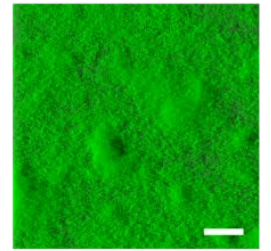

$0 \mathrm{~h}$

Before treatment

C

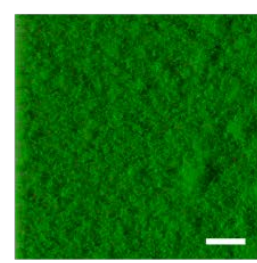

$2 \mathrm{~h}$
Control

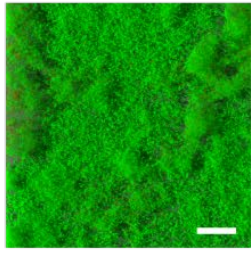

$24 \mathrm{~h}$

No treatment

\begin{abstract}
Chitosan
\end{abstract}

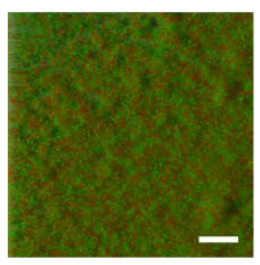

$7 \mathrm{~h}$

After treatment

$\mathbf{E}$

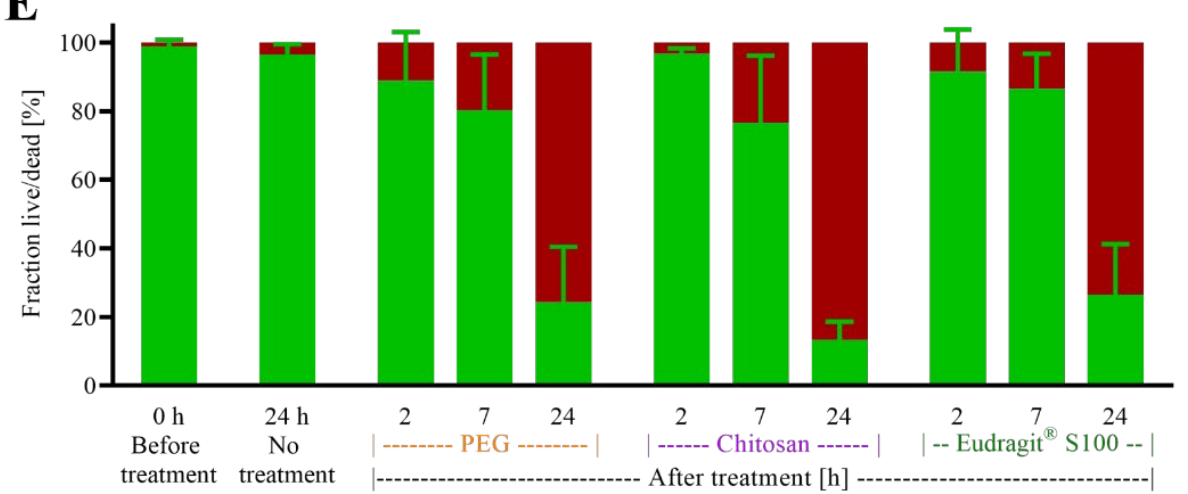

B

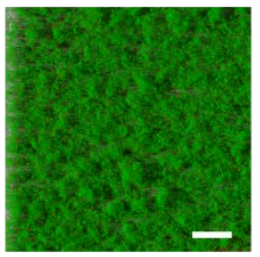

$2 \mathrm{~h}$

D

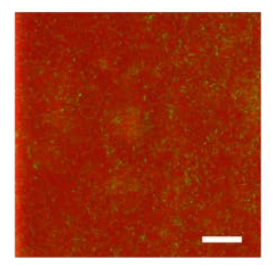

$24 \mathrm{~h}$

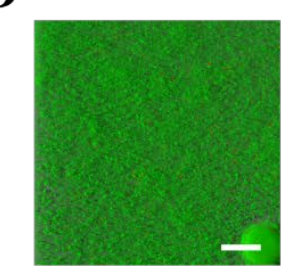

$2 \mathrm{~h}$
PEG

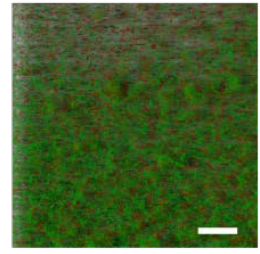

$7 \mathrm{~h}$

After treatment

Eudragit $\left.^{(}\right) \mathrm{S} 100$

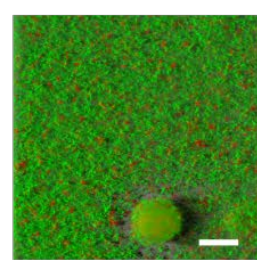

$7 \mathrm{~h}$

After treatment

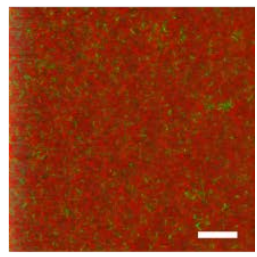

$24 \mathrm{~h}$

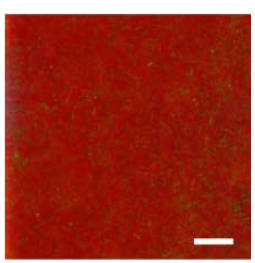

$24 \mathrm{~h}$ 


\section{WILEY-VCH}

A

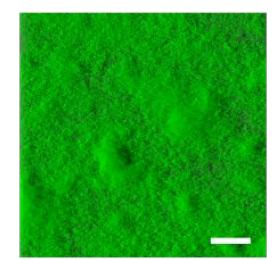

$0 \mathrm{~h}$

Before treatment

C

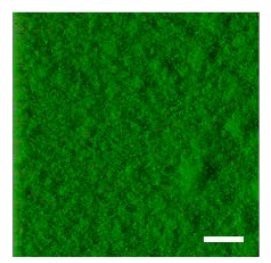

$2 \mathrm{~h}$
Control

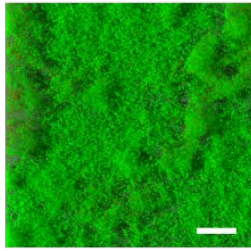

$24 \mathrm{~h}$

No treatment

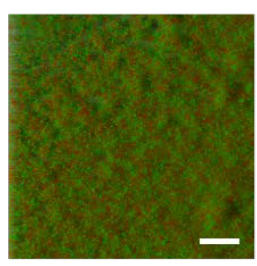

$7 \mathrm{~h}$
Live
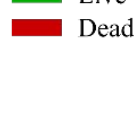

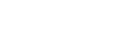

B

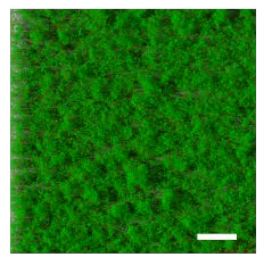

$2 \mathrm{~h}$

D

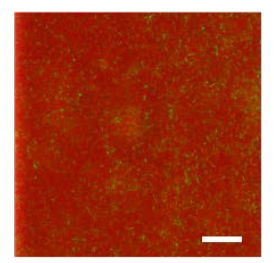

$24 \mathrm{~h}$

After treatment

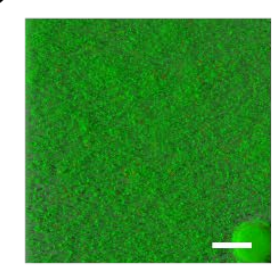

$2 \mathrm{~h}$
PEG

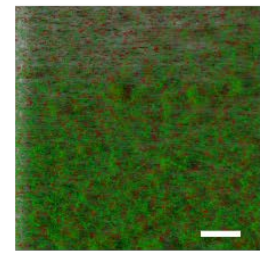

$7 \mathrm{~h}$

After treatment

Eudragit S100

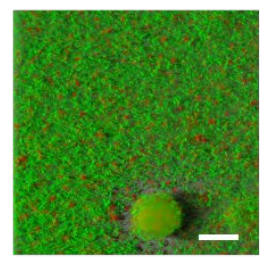

$7 \mathrm{~h}$

After treatment

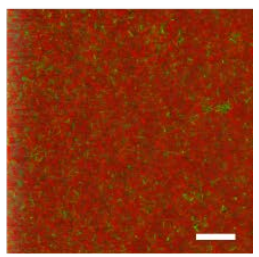

$24 \mathrm{~h}$

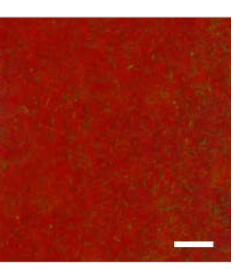

$24 \mathrm{~h}$

E

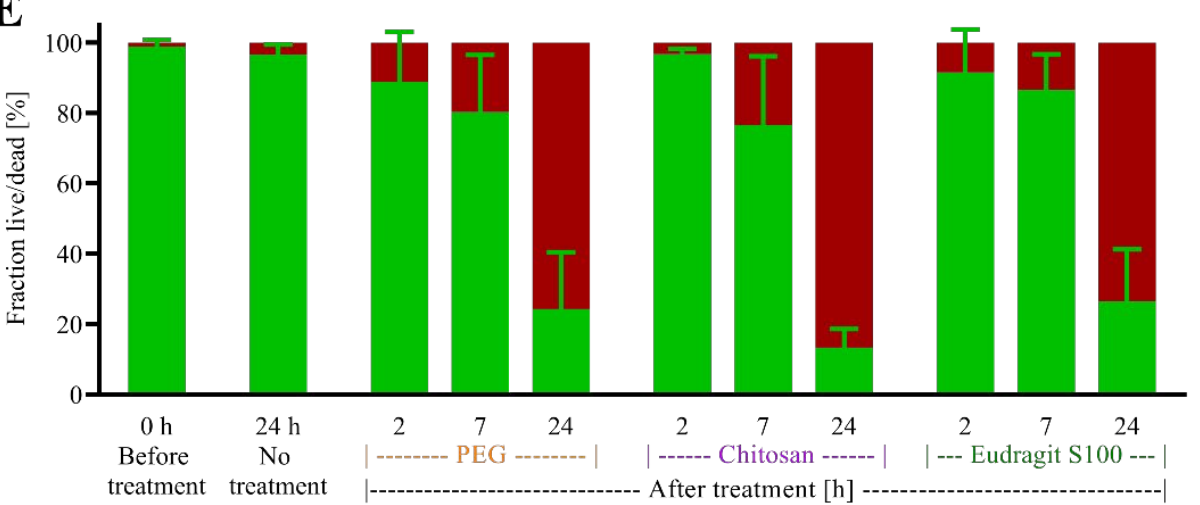

Figure 5. PAO1 biofilm grown for $96 \mathrm{~h}$ under flow to a mature state, and thereafter exposed to app. $120 \mu \mathrm{g}$ ciprofloxacin hydrochloride (CIP) confined in microcontainers coated with either polyethylene glycol (PEG), chitosan or Eudragit ${ }^{\mathbb{B}}$ S100. A-D) Confocal scanning laser microscopy (CSLM) images of mature biofilm before treatment and 2,7 and $24 \mathrm{~h}$ after treatment with polymer-coated microcontainers as well as a $24 \mathrm{~h}$ untreated control. Scale bar: $30 \mu \mathrm{m}$. E) Quantitative analysis of the biomass $\left(\mu \mathrm{m}^{3} \mu \mathrm{m}^{-2}\right)$ converted to the fraction of live/dead (\%). Green represents live bacteria. Red represents dead bacteria. Data are depicted as mean $+\mathrm{SD}(\mathrm{n}=4-24)$.

519 After $2 \mathrm{~h}$ of treatment with CIP-loaded microcontainers, containing app. $120 \mu \mathrm{g}$ CIP in total, limited bacterial killing occurred, with an average dead biomass of $11.1 \pm 14.2 \%, 3.3 \pm 1.5 \%$ and $8.5 \pm 12.2 \%$ for PEG, chitosan and Eudragit ${ }^{\circledR}$ S100 coatings, respectively. At this time point, PEG coating led to the greatest amount of CIP released $(61.3 \%)$ compared to chitosan and Eudragit ${ }^{\circledR} \mathrm{S} 100(28.1 \%$ and $23.6 \%$, respectively) (cf. Figure 2A). The differences in amount of released CIP were paralleled by

524 the mean killing of biofilm-associated PAO1 cells after 2 h. Note, however, that utilizing a PEG coating with a faster release did not significantly improve the killing compared to the sustained release achieved with chitosan and Eudragit ${ }^{\circledR}$ S100. After $7 \mathrm{~h}$, the dead bacterial fraction increased to 


\section{WILEY-VCH}

$19.7 \pm 16.2 \%, 23.5 \pm 19.6 \%$ and $13.5 \pm 10.2 \%$ for PEG, chitosan and Eudragit ${ }^{\circledR}$ S100, respectively. All coatings reduced bacterial motility after $7 \mathrm{~h}$ compared to $2 \mathrm{~h}$. In addition, bacterial morphology changed as the bacteria appeared coccoid, a sign of slow growth and starvation. ${ }^{[37]}$ At the same time many bacteria appeared extremely elongated indicating that they are stressed and still metabolically active, but cell division is inhibited. ${ }^{[37]}$ This observation correlates with the reported mechanism of ciprofloxacin, which interferes with DNA replication and transcription by inhibiting of topoisomerase II (also known as DNA gyrase) and topoisomerase IV, thereby inhibiting cell division. ${ }^{[1]}$ When planktonic PAO1 cells were treated with coated microcontainers, a significant killing was observed after $8 \mathrm{~h}$ (cf. Figure 3). Microcontainer therefore had a faster and more effective impact on planktonic cell inhibition, which correlates with previous reported decreased antibiotic tolerance of planktonic bacteria compared to the biofilm-associated cells. ${ }^{[1]}$ After treating for $24 \mathrm{~h}$, in which almost all antibiotic had been released from the microcontainers, the live population of PAO1 were significantly reduced and the dead biomass increased to $75.7 \pm 16.2 \%, 88.2 \pm 5.3 \%$ and $73.6 \pm 14.8 \%$ for PEG, chitosan and Eudragit ${ }^{\circledR}$ S100, respectively.

Altogether, the uncharged PEG coating did not appear to improve the antimicrobial effect compared to the anionic, non-mucoadhesive Eudragit ${ }^{\circledR}$ S100 coating, whereas the cationic chitosan coating appeared to be the most promising coating (Figure 5). Interestingly, the charge of the polymers did not appear to have any prominent effect on the eradication of the biofilm. Du et al. reported a 3.2fold increase in elimination of an established $P$. aeruginosa biofilm when treating with PEGconjugated tobramycin compared to the effect of a solution of the antibiotic. ${ }^{[38]}$ Moreover, Suk et al. showed that low MW PEG-coated nanoparticles moved through undiluted cystic fibrosis sputum up to 90 -fold faster than uncoated particles, but the penetration of identically coated larger nanoparticles were strongly hindered. ${ }^{[39]}$ For this reason, larger particles or devices like the microcontainers coated with PEG are likely to be mostly mucoadhesive, however, this did not improve the bacterial killing as no difference between PEG and Eudragit ${ }^{\circledR}$ S100 coating was observed. Chitosan has previously 


\section{WILEY-VCH}

552 been shown to be mucoadhesive presumably due to hydrogen bonding and ionic interactions with the

553 negatively charged mucins. ${ }^{[26]}$ The same mechanism may be relevant in the biofilm, in which the 554 positively charged chitosan can interact with the negatively charged components of the EPS (such as 555 alginate ${ }^{[40]}$, hence increasing adhesion. In addition, Machul et al. reported an inhibitory effect of 556 chitosan on both planktonic as well as biofilm-associated $P$. aeruginosa ${ }^{[27]}$ The chitosan may interact 557 with the negatively charged microbial cell membranes causing leakage of the intracellular 558 components hence cell disintegration. ${ }^{[24,26]}$ Both the additional antimicrobial effect as well as 559 improved adhesion might have contributed to the enhanced killing observed when using chitosan 560 coating in this study.

2.4.1. Impact of one bolus dose or constant perfusion of ciprofloxacin hydrochloride on PAO1 biofilm

563 To determine whether CIP confined in microcontainers would provide improved killing compared to 564 the same dose of unconfined antibiotic given as one bolus injection, a $96 \mathrm{~h}$ old PAO1 biofilm was 565 treated with one bolus dose of $120 \mu \mathrm{g}$ CIP and images were acquired 2, 7 and $24 \mathrm{~h}$ after exposure. 566 After 2 h, $26.7 \pm 25.4 \%$ was found dead and no significant change occurred the following $24 \mathrm{~h}$ (Figure 567 6). In absence of antibiotics, the biofilm biomass showed minimal killing after $24 \mathrm{~h}$ as expected. 568 These findings indicate that using the same dose of CIP but confining it in microcontainers improved the in vitro antibacterial properties of CIP significantly. 


\section{WILEY-VCH}

A

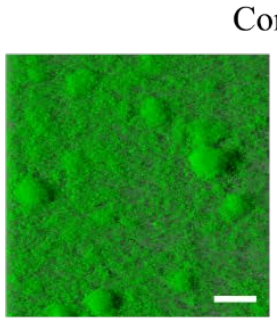

$0 \mathrm{~h}$

Before treatment

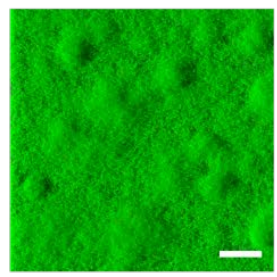

$24 \mathrm{~h}$

No treatment
B

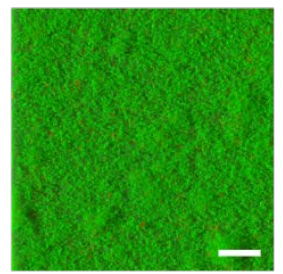

$2 \mathrm{~h}$
Bolus dose

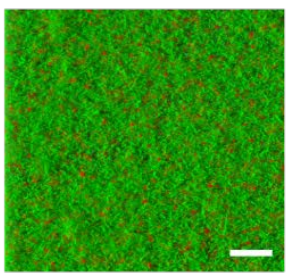

$7 \mathrm{~h}$

After treatment

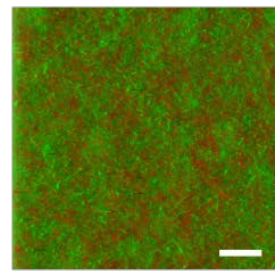

$24 \mathrm{~h}$

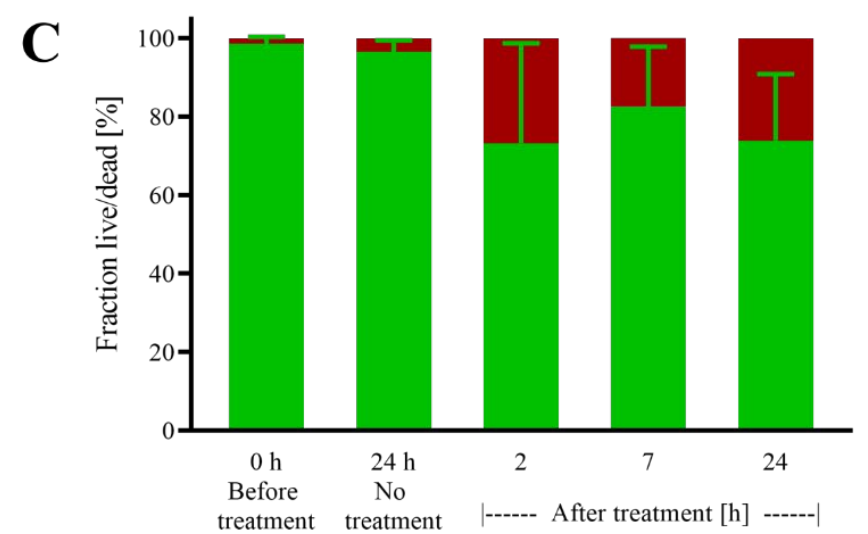

571

Figure 6. PAO1 biofilm grown for $96 \mathrm{~h}$ under flow to a mature state and thereafter exposed to one bolus injection of $60 \mu \mathrm{g} \mathrm{mL}^{-1}$ ciprofloxacin hydrochloride (CIP) with a total dose of $120 \mu \mathrm{g}$. A-B) Confocal scanning laser microscopy images of the biofilm before treatment and 2, 7 and $24 \mathrm{~h}$ after treatment as well as a $24 \mathrm{~h}$ control biofilm not treated. Scale bar: $30 \mu \mathrm{m}$. C) Quantitative analysis of the biomass $\left(\mu \mathrm{m}^{3} \mu \mathrm{m}^{-2}\right)$ converted to the fraction of live/dead (\%). Green represents live bacteria. Red represents dead bacteria. Data are depicted as mean+SD $(n=3)$.

Moreover, a $96 \mathrm{~h}$ old PAO1 biofilm was perfused with CIP in a concentration of $4 \mu \mathrm{g} \mathrm{mL}^{-1}$ for $24 \mathrm{~h}$, corresponding to a total amount of $330 \mu \mathrm{g}$ CIP delivered to the biofilm. The perfusion resulted in $82.0 \pm 6.2 \%$ killing of the total amount of biomass after $24 \mathrm{~h}$ (Figure 7). In control chambers, PAO1 cells were still alive and the biomass increased over $24 \mathrm{~h}$ as expected. Comparing these results to biofilm treatment with CIP confined in microcontainers (cf. Figure 5E), it was found that microcontainers provided bacterial killing similar to a 2.75 times higher concentration of solubilized antibiotic constantly perfused. Therefore, it appears that confining CIP in microcontainers is a promising strategy, providing the same antibacterial effect with a significantly reduced amount of antibiotic. 
WILEY-VCH

A

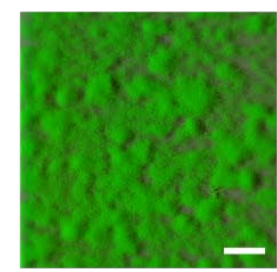

$0 \mathrm{~h}$

Before treatment

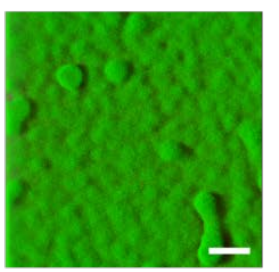

$24 \mathrm{~h}$

No treatment

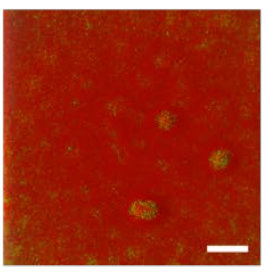

$24 \mathrm{~h}$

After treatment
B

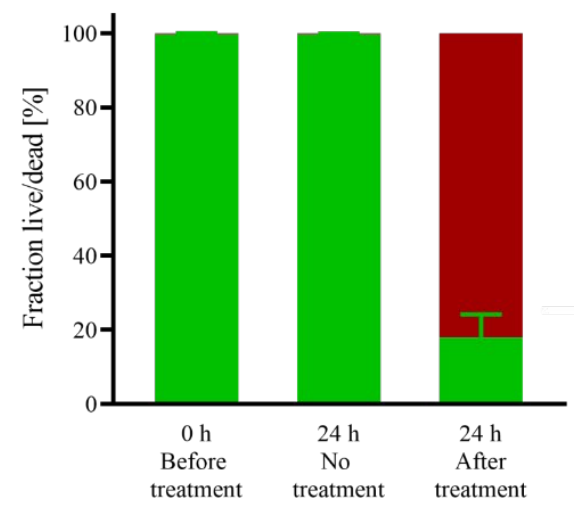

Figure 7. PAO1 biofilm grown for $96 \mathrm{~h}$ under flow to a mature state and thereafter exposed to perfusion of $4 \mu \mathrm{g} \mathrm{mL} \mathrm{m}^{-1} \mathrm{ciprofloxacin}$ hydrochloride (CIP) for $24 \mathrm{~h}$ corresponding to a total amount of $330 \mu \mathrm{g}$ CIP delivered to the biofilm. A) Confocal scanning laser microscopy images of the biofilm before treatment, after $24 \mathrm{~h}$ with no treatment and after $24 \mathrm{~h}$ treatment with CIP. Scale bar: $30 \mu \mathrm{m}$. B) Quantitative analysis of the biomass $\left(\mu \mathrm{m}^{3} \mu \mathrm{m}^{-2}\right)$ converted to the fraction of live/dead (\%). Green represents live bacteria. Red represents dead bacteria. Data are depicted as mean $+\mathrm{SD}(\mathrm{n}=5)$.

No complete eradication of PAO1 biofilm was observed in any of the treatments tested, since 10-20\% of the biomass remained alive despite treatment with CIP confined in microcontainers or as constant perfusion. The remaining fraction might be a subpopulation of antibiotic-tolerant persister cells in a temporary dormant state in which cell division is minimized. ${ }^{[41,42]}$ Many antibiotics (including ciprofloxacin) require a certain degree of metabolic activity in the cells to be effective as the mechanism of action often involves disruption of the cellular processes. ${ }^{[4]}$ To achieve a full eradication therapy on the biofilm cells with microcontainers, it is possible that delivery of a nutritionrich compound prior to antibiotic therapy may stimulate bacterial growth, and thus improve the antibiotic efficacy.

Using microcontainers to achieve a site-specific delivery of antibiotics could potentially reduce the required dose, and thereby reduce the risk of resistance development. The local delivery would also prevent antibiotic exposure in the gastrointestinal tract and its microbiota, thereby decreasing the risk of gastrointestinal side effects often seen for patients needing antibiotics for extended time periods. ${ }^{[9]}$ The microcontainers could potentially be used to prevent recurring infections and to treat initial and chronic infections. An additional benefit of the microcontainers is the possibility of personalizing the 


\section{WILEY-VCH}

606 treatment, by dosing the amount of microcontainers needed for treatment of a certain infection in 607 different patients.

608

609

610

611

612

613

614

615

\section{Conclusion}

Microcontainers were successfully loaded with CIP and functionalized with lids of PEG, chitosan or Eudragit ${ }^{\circledR}$ S100. Release profiles from coated microcontainers showed that PEG facilitated a faster release of CIP, whereas Eudragit ${ }^{\circledR}$ S100 and chitosan gave rise to a sustained release. All antibiotic containing microcontainers inhibit planktonic growth of PAO1 cells, but the degree of inhibition depends on the choice of coating. Treating a mature PAO1 biofilm with a bolus dose of CIP only resulted in killing of a $26.1 \pm 16.9 \%$ of the biofilm cells after $24 \mathrm{~h}$. The same dose confined in coated microcontainers killed $75.7 \pm 16.2 \%, 88.2 \pm 5.3 \%$ and $73.6 \pm 14.8 \%$ of the biomass in close proximity to the microcontainer, when using PEG, chitosan and Eudragit ${ }^{\circledR}$ S100 coatings, respectively. Microcontainers provided bacterial killing similar to a 2.75 times higher concentration of solubilized antibiotic constantly perfused. This proves that using microcontainers as a delivery system for antibiotic treatment of biofilm-associated infections could be a promising new strategy.

\section{Experimental Section}

\subsection{Fabrication of microcontainers}

Microcontainers were fabricated on silicon wafers as previously described with two-steps of photolithography using the negative epoxy-based photoresist SU-8. ${ }^{[43]}$ Silicon wafers (4-in. b100N n-type) were supplied by Okmetic, Vantaa, Finland, whereas SU-8 2075 and SU-8 developer were purchased from Microresist Technology GmbH (Berlin, Germany). For biofilm assays, the microcontainers were fabricated on top of a fluorocarbon coated silicon wafer enabling detachment of single microcontainers from the wafer, ${ }^{[4]}$ whereas for the other studies, the microcontainers were fabricated directly on the silicon wafer. ${ }^{[43]}$ The wafers with the fabricated microcontainers were cut into chips of $12.8 \times 12.8 \mathrm{~mm}^{2}$, containing 625 microcontainers on each chip, using a laser cutter 


\section{WILEY-VCH}

630 (microSTRUCT vario, 3D Microac AG, Chemnitz, Germany). The dimensions of the

631 microcontainers were measured on an Alpha-Step IQ Stylus Profilometer (KLA-Tencor Corporation, 632 Milpitas, USA).

\section{4.2. Loading ciprofloxacin hydrochloride in microcontainers}

634 A mask was used to cover the gaps between the microcontainers to allow only drug loading in the 635 cavity of the microcontainers. ${ }^{[45]}$ The microcontainers were then manually loaded with CIP (Fagron, 636 Uitgeest, The Netherlands) by distributing powder over a chip with microcontainers using a small 637 brush. The mask was gently removed after loading and any excess of drug in between the 638 microcontainers was removed with pressurized air. The chips with microcontainers were weighed 639 before and after loading to determine the amount of drug loaded into the microcontainers

\subsection{Deposition of a lid on ciprofloxacin hydrochloride-loaded microcontainers}

641 The microcontainers were coated with three different lids of either PEG, chitosan or Eudragit ${ }^{\circledR}$ S100. 642 A $2.66 \%$ w/v solution of low molecular weight 11-15 kDa PEG (Sigma Aldrich, St. Louis, USA) in 643 water was made. The chitosan solution was prepared in a $0.5 \% \mathrm{w} / \mathrm{v}$ concentration by dissolving low 644 molecular weight chitosan (12 kDa, 75-85 \% deacetylated, Sigma Aldrich, St. Louis, USA) in 0.1 M 645 acetic acid (Sigma Aldrich, St. Louis, USA). After dissolving, the chitosan solution was filtered using 646 a 5-13 $\mu \mathrm{m}$ filter with vacuum suction. A solution of $1 \% \mathrm{w} / \mathrm{v}$ Eudragit ${ }^{\circledR} \mathrm{S} 100$ (Evonik Industries, 647 Darmstadt, Germany) and $5 \% \mathrm{w} / \mathrm{w}$ in relation to the polymer of dibutyl sebacate (Sigma Aldrich, St. 648 Louis, USA) was dissolved in isopropanol (Honeywell, Muskegon, USA). The solutions were 649 sprayed on top of the CIP-loaded microcontainers using a spray coating system equipped with an 650 ultrasonic nozzle actuated at $120 \mathrm{kHz}$ (ExactaCoat, Sono Tek, USA). The nozzle of the spray coater 651 moved across the microcontainer chip in a $x-y$ path covering the area of the chip. One loop 652 corresponded to the nozzle moving across the sample twice, with an offset of $2 \mathrm{~mm}$ in the $\mathrm{x}$ direction 
653 the second time as the beam diameter was $4 \mathrm{~mm}$. Z-distance represents the distance between the spray 654 nozzle and the sample (Table 1).

655 Table 1. Parameters used for ultrasonic spray coating with either $2.66 \% \mathrm{w} / \mathrm{v}$ polyethylene glycol (PEG), $0.5 \% \mathrm{w} / \mathrm{v}$ chitosan or $1 \%$ 656 $\mathrm{w} / \mathrm{v}$ Eudragit ${ }^{\circledR}$ S100 applied on ciprofloxacin hydrochloride (CIP)-loaded microcontainers.

\begin{tabular}{|c|c|c|c|}
\hline Coating parameters & PEG & Chitosan & Eudragit $^{\circledR}$ S100 \\
\hline Path speed $\left(\mathrm{mm} \mathrm{s}^{-1}\right)$ & 20 & 25 & 10 \\
\hline Infusion rate $\left(\mathrm{mL} \mathrm{min}{ }^{-1}\right)$ & 0.1 & 0.1 & 0.1 \\
\hline Generator power (W) & 1.3 & 1.3 & 2.2 \\
\hline Shaping air pressure $(\mathrm{kPa})$ & 0.02 & 0.03 & 0.02 \\
\hline Heat plate temperature $\left({ }^{\circ} \mathrm{C}\right)$ & 40 & 50 & 40 \\
\hline Z-distance from nozzle to sample $(\mathrm{cm})$ & 6.0 & 5.5 & 3.0 \\
\hline No. of loops & 150 & 120 & 30 \\
\hline
\end{tabular}

658 The thickness of the coatings was evaluated using a contact Profilometer (Alpha-Step IQ Stylus 659 Profilometer, KLA-Tencor, Corporation, Milpitas, USA). Each of the polymers was sprayed on top 660 of a flat silicon chip covered with a layer of SU-8. Half of the chip was covered by a glass cover slip 661 hence, enabling coating of only half a chip suitable for height evaluation. The height profiles were 662 measured using an $8 \mathrm{mg}$ tip force with a scan speed of $50 \mu \mathrm{m} \mathrm{s}^{-1}$ and a sampling rate of $50 \mathrm{~Hz}$. 663 Measurements were conducted at three different locations on each coated chip and presented as 664 mean \pm SD.

\section{4.4. Scanning electron microscopy of the microcontainers}

666 The quality of the loading and the coating was evaluated using a Tabletop SEM (Hitachi High667 Technologies Europe GmbH, Krefeld, Germany). The chips with microcontainers were placed on a $66830^{\circ}$ tilted holder and SEM images were acquired using the scattered electron (SE) detector and an 669 accelerating voltage of $15 \mathrm{kV}$ for highest quality images. 


\section{WILEY-VCH}

\subsection{In vitro release of ciprofloxacin hydrochloride from microcontainers}

The in vitro release of CIP from the microcontainers was measured using a $\mu$ Diss Profiler (Pion Inc. Wobrun, MA, USA) at a constant temperature of $37^{\circ} \mathrm{C}$. Stirring rate was kept at $100 \mathrm{RPM}$ and the absorbance was measured in situ at $350 \mathrm{~nm}$. The path length of the UV probes was $5 \mathrm{~mm}$. Each probe of the $\mu$ Diss was calibrated prior to each release study. Each chip with CIP-loaded microcontainers was attached to cylindrical magnetic stirrers with carbon tape and placed in a glass vial. Modified FAB medium was prepared as described in Sup. Info, Table S1 with a $\mathrm{pH}$ of 6.8 and $\mathrm{pH} 7.4$. The chips were covered with $20 \mathrm{~mL}$ of FAB medium $\mathrm{pH} 6.8$ and CIP release from microcontainers was measured for 18-40 h depending on the polymer coating. For Eudragit ${ }^{\circledR} \mathrm{S} 100$, the chips were placed in FAB medium at pH 6.8 for 15 min and subsequently, in FAB medium adjusted to $\mathrm{pH} 7.4$. The percentage of drug release to each time point was calculated from the known amount of drug loaded per chip and presented as mean $\pm \mathrm{SD}$. The release studies were in 3-6 replicates for uncoated microcontainers and microcontainers coated with either PEG, chitosan or Eudragit ${ }^{\circledR} \mathrm{S} 100$.

\subsection{Bacterial strain and media preparation}

P. aeruginosa PAO1 was genetically modified to express green fluorescent protein (GFP) constitutively by insertion into a neutral intergenic region in the genome with no impact on the cell growth physiology. ${ }^{[6,46,47]}$ An overnight culture of PAO1 was prepared from a $-80^{\circ} \mathrm{C}$ stock by inoculating a small amount into $5 \mathrm{~mL}$ LB and allowing growth until stationary phase for $12-16 \mathrm{~h}$ at $37^{\circ} \mathrm{C}$ at 150 RPM. Plate assays were conducted in LB medium. Biofilms were grown in modified FAB minimal medium with trace metals suitable for PAO1 growth and with glucose as the only carbon source (Sup. Info, Table S1). ${ }^{[33]}$

\subsection{Planktonic growth of PAO1 and growth inhibition testing}

To study the ability of microcontainers to inhibit bacterial growth, a PAO1 overnight culture was diluted to an optical density $\left(\mathrm{OD}_{600}\right)$ of 0.05 in $20 \mathrm{~mL}$ of $\mathrm{LB}$ medium adjusted to $\mathrm{pH}$ 6.8, except when 


\section{WILEY-VCH}

694 used with Eudragit ${ }^{\circledR}$ S100 where $\mathrm{pH}$ was pH 7.4. One microcontainer either being empty or loaded with CIP or loaded with CIP and coated with PEG, chitosan or Eudragit ${ }^{\circledR}$ S100 was added to each flask. For the control with CIP in solution, $20 \mu \mathrm{L}$ of a $0.22 \mathrm{mg} / \mathrm{ml}$ CIP solution was added to the flask. The flasks were placed in a $37^{\circ} \mathrm{C}$ incubator at $150 \mathrm{RPM}$. Samples were taken at selected time points between $20 \mathrm{~min}$ and $24 \mathrm{~h}$ after introduction of the microcontainer. Bacterial density was monitored using OD measurements at $600 \mathrm{~nm}$ on an automated plate reader (Synergy H1, BioTek, USA). Viable counts were obtained after 3,8 and 24 h by serial dilution followed by spot plating on LB agar plates. The plates were left to incubate overnight at $37^{\circ} \mathrm{C}$ and $\mathrm{CFU}$ were counted the following day.

\subsection{Setup of flow system to grow biofilms}

Biofilms of PAO1 were grown at $37^{\circ} \mathrm{C}$ under laminar flow in flow chambers at $58.4 \mu \mathrm{L} / \mathrm{min}$ with a 16-channel Watson Marlow pump as described by Tolker-Nielsen et al. ${ }^{[48]}$ However, the flow cells were slightly modified implementing an inlet channel on the side of the flow chamber to allow inoculation of the microcontainers. Sterilization of the flow system was performed by pumping $1 \mathrm{~L}$ of $0.5 \% \mathrm{v} / \mathrm{v}$ hypochlorite through the system over a period of $4 \mathrm{~h}$ followed by a cleaning procedure with filling and emptying the system 3 times with $2 \mathrm{~L}$ of autoclaved MilliQ water. Thereafter, the system was filled with FAB medium at $\mathrm{pH} 6.8$ and left with a flow of $58.4 \mu \mathrm{L} / \mathrm{min}$ overnight to allow saturation of the tubings with the medium. The medium flow in the system was stopped and inlet was

711 clamped to avoid backflow. The inlet silicone tube was wiped with $70 \% \mathrm{v} / \mathrm{v}$ ethanol and $250 \mu \mathrm{L}$ of 712 a diluted overnight culture (with $0.9 \% \mathrm{NaCl}$ to $\mathrm{OD}_{600}$ of 0.05 ) was inoculated carefully into the flow 713 chamber. The inlet needle hole was wiped with ethanol and resealed with a thin layer of silicone glue. 714 To allow the bacteria to attach to the glass surface the flow chambers were left for $1 \mathrm{~h}$ without flow 715 before medium flow was resumed. Bacterial biofilms were allowed to develop for $96 \mathrm{~h}$ before antibiotic treatment. 


\section{WILEY-VCH}

4.8.1. Treating PAO1 biofilm with ciprofloxacin hydrochloride confined in coated microcontainers For inoculation of microcontainers, a solution of $2.5 \% \mathrm{w} / \mathrm{v}$ gelatin (Sigma Aldrich Chemie GmbH, Steinheim, Germany) was used to allow the microcontainer to be dispersed in the syringe instead of sticking to the walls. The gelatin was weighed into sterile tubes and dissolved in $100 \mathrm{~mm}$ phosphatebuffered saline (adjusted to $\mathrm{pH}$ 6.8) in a water bath at $37^{\circ} \mathrm{C}$ and $100 \mathrm{RPM}$. For sterilization purposes, chloroform (Sigma Aldrich, St. Louis, USA) was added to the gelatin solution with a final concentration of $0.5 \% \mathrm{v} / \mathrm{v}$. The tubes were stored at room temperature. Chloroform evaporation was allowed and the microcontainers coated with either PEG, Chitosan or Eudragit ${ }^{\circledR}$ S100 were added to the gelatin just prior to the experiment. Microcontainers loaded with app. $120 \mu \mathrm{g}$ CIP in total were introduced into the flow cell and the system was left without flow for $15 \mathrm{~min}$ before staring the flow again. In Eudragit ${ }^{\circledR}$ S100 channels the $\mathrm{pH}$ of the medium was increased to 7.4. Images used for quantification purposes were acquired at a distance of $140-320 \mu \mathrm{m}$ from the open side of the microcontainer, as the presence of the microcontainer in the image would interfere with the quantitative COMSTAT analysis (see Section 4.9).

\subsubsection{Treating PAO1 biofilm with unconfined ciprofloxacin hydrochloride as bolus dose or as} constant perfusion

A $96 \mathrm{~h}$ old PAO1 biofilm was treated with unconfined CIP in two ways: 1) as a single bolus dose or 2) as a constant perfusion. When treating with one bolus dose, the tubing after the bubble traps were clamped off and $2 \mathrm{~mL}$ of a $60 \mu \mathrm{g} \mathrm{mL} \mathrm{m}^{-1} \mathrm{CIP}$ solution were introduced into the system, corresponding to a total dose of $120 \mu \mathrm{g}$ of CIP. Tubings were afterwards sealed with silicone. For the perfusion study, the medium bottle was changed with a medium bottle containing $4 \mu \mathrm{g} \mathrm{mL}^{-1}$ of CIP and medium in bubble traps was exchanged with antibiotic-containing medium. The biofilm was treated for $24 \mathrm{~h}$ corresponding to a total delivered dose of $330 \mu \mathrm{g}$. 


\section{WILEY-VCH}

740 4.9. Microscopy parameters, image acquisition and analysis

741 Microscopic observations of bacterial biofilms and microcontainers were completed using an inverted 742 Leica TCS SP8 CLSM (Mannheim, Germany) equipped with an argon/krypton laser and detectors 743 and filter sets for simultaneous monitoring of GFP (excitation: $488 \mathrm{~nm}$, emission: 493-558 nm) for 744 live cell imaging and propidium iodide (excitation: $543 \mathrm{~nm}$, emission: 558-700 nm) for dead cell 745 staining. Sequential line scanning was used to avoid cross talk. Images were obtained using an HC 746 PL Apo CS2 63x oil objective (numerical aperture 1.4). Propidium iodide was injected into the top 747 of the bubble traps and allowed to flow into the flow chambers for 10 min prior to image acquisition. 748 Images were acquired with z-intervals of $1 \mu \mathrm{m}$. As control, six biological experiments were 749 performed acquiring two images (technical replicates) of non-treated biofilm in each experiment at 750 random positions within the flow cell to account for any heterogeneity within the biofilm. Stacked 751 images were generated using Imaris software (Version 7.7.1, Bitplane AG, Zürich, Switzerland). 752 Volume of biomass was calculated using the image-analysis COMSTAT version 2.1 software. ${ }^{[33,49]}$ 753 Graphs depicting the fraction of live/dead biomass were generated by calculating the percentage of 754 live/dead in relation to the total biomass measured either before treatment $(0 \mathrm{~h})$, after $24 \mathrm{~h}$ without 755 treatment as control or 2,7 and $24 \mathrm{~h}$ after treatment.

\subsection{Statistical analysis}

757 Data are expressed as the mean \pm SD unless otherwise noted. For comparison of two individual mean 758 values an unpaired t-test was applied, whereas a one-way ANOVA with Tukey's multiple comparison 759 was used if more than two mean values were compared. Graphs and tests were conducted in GraphPad

760 Prism (Version 8.0.1, GraphPad Software, CA, USA) and p-values were considered statistically 761 significant when below $5 \%(\mathrm{p}<0.05)$. 


\section{WILEY-VCH}

763

764

765

766

767

768

769

770

771

772

773

$\underline{\text { Supporting information }}$

Supporting Information is available from the Wiley Online Library or from the author.

\section{Conflict of interest}

The authors declare no conflict of interest.

\section{$\underline{\text { Acknowledgements }}$}

The authors would like to acknowledge the Center for Intelligent Drug Delivery and Sensing Using Microcontainers and Nanomechanics (IDUN) whose research is funded by the Danish National Research Foundation (DNRF122) and Villum Foundation (Grant No. 9301). Micro- and nanofabrication specialist Lasse Højlund Eklund Thamdrup, DTU Health Tech is thanked for help with fabrication of the microcontainers. Furthermore, associate Professor Claus Sternberg, DTU Bioengineering is greatly acknowledged for providing access to the confocal scanning laser microscope as well as help with the quantitative program Comstat. In addition, Nanna Bild, DTU Health Tech is acknowledged for her kind help with drawing of the graphical abstract. Helle Krogh Johansen was supported by The Novo Nordisk Foundation as a clinical research stipend (NNF12OC1015920), by Rigshospitalets Rammebevilling 2015-17 (R88-A3537), by Lundbeckfonden (R167-2013-15229), by Novo Nordisk Fonden (NNF15OC0017444, NNF18OC0052776), by RegionH Rammebevilling (R144-A5287) and by Independent Research Fund Denmark/Medical and Health Sciences (FSS-4183-00051, DFF-9039-00037A). 


\section{WILEY-VCH}

\section{References}

[1] D. Davies, Nat. Rev. Drug Discovery 2003, 2, 114.

[2] N. Høiby, T. Bjarnsholt, M. Givskov, S. Molin, O. Ciofu, Int. J. Antimicrob. Agents 2010, 35 , 322.

[3] J. W. Costerton, P. S. Stewart, E. P. Greenberg, Science 1999, 284, 1318.

[4] L. Hall-Stoodley, J. W. Costerton, P. Stoodley, Nat. Rev. Microbiol. 2004, 2, 95.

[5] M. Burmølle, T. R. Thomsen, M. Fazli, I. Dige, L. Christensen, P. Homøe, M. Tvede, B. Nyvad, T. Tolker-Nielsen, M. Givskov, C. Moser, K. Kirketerp-Møller, H. K. Johansen, N. Høiby, P. Ø. Jensen, S. J. Sørensen, T. Bjarnsholt, FEMS Immunol. Med. Microbiol. 2010, 59, 324.

[6] C. K. Stover, X. Q. Pham, A. L. Erwin, S. D. Mizoguchi, P. Warrener, M. J. Hickey, F. S. Brinkman, W. O. Hufnagle, D. J. Kowalik, M. Lagrou, R. L. Garber, L. Goltry, E. Tolentino, S. Westbrock-Wadman, Y. Yuan, L. L. Brody, S. N. Coulter, K. R. Folger, A. Kas, K. Larbig, R. Lim, K. Smith, D. Spencer, G. K. Wong, Z. Wu, I. T. Paulsen, J. Reizer, M. H. Saier, R. E. Hancock, S. Lory, M. V Olson, Nature 2000, 406, 959.

[7] P. Markou, Y. Apidianakis, Front. Cell. Infect. Microbiol. 2014, 3, 1.

[8] I. Y. Hwang, E. Koh, A. Wong, J. C. March, W. E. Bentley, Y. S. Lee, M. W. Chang, Nat. Commun. 2017, 8, 1.

[9] S. Kłodzińska, P. Priemel, T. Rades, H. Mørck Nielsen, Int. J. Mol. Sci. 2016, 17, 1688.

[10] R. Osman, P. L. Kan, G. Awad, N. Mortada, A. E. El-Shamy, O. Alpar, Int. J. Pharm. 2013, $449,44$.

[11] K. J. Aldred, R. J. Kerns, N. Osheroff, Biochemistry 2014, 53, 1565.

[12] X. Li, Y. C. Yeh, K. Giri, R. Mout, R. F. Landis, Y. S. Prakash, V. M. Rotello, Chem. Commun. 2015, 51, 282.

[13] Y. Liu, L. Shi, L. Su, H. C. Van der Mei, P. C. Jutte, Y. Ren, H. J. Busscher, Chem. Soc. Rev. 2019, 48, 428.

[14] T. Bjarnsholt, P. Ø. Jensen, M. J. Fiandaca, J. Pedersen, C. R. Hansen, C. B. Andersen, T. Pressler, M. Givskov, N. Høiby, Pediatr. Pulmonol. 2009, 44, 547.

[15] J. R. Jørgensen, M. L. Jepsen, L. H. Nielsen, M. Dufva, H. M. Nielsen, T. Rades, A. Boisen, A. Müllertz, Eur. J. Pharm. Biopharm. 2019, 143, 98.

[16] K. M. Ainslie, C. M. Kraning, T. A. Desai, Lab Chip 2008, 8, 1042.

[17] L. H. Nielsen, S. S. Keller, A. Boisen, Lab Chip 2018, 18, 2348.

[18] L. H. Nielsen, A. Melero, S. S. Keller, J. Jacobsen, T. Garrigues, T. Rades, A. Müllertz, A. Boisen, Int. J. Pharm. 2016, 504, 98.

[19] C. Mazzoni, F. Tentor, S. A. Strindberg, L. H. Nielsen, S. S. Keller, T. S. Alstrøm, C. Gundlach, A. Müllertz, P. Marizza, A. Boisen, J. Controlled Release 2017, 268, 343.

[20] C. Mazzoni, R. D. Jacobsen, J. Mortensen, J. R. Jørgensen, L. Vaut, J. Jacobsen, C. Gundlach, A. Müllertz, L. H. Nielsen, A. Boisen, Macromol. Biosci. 2019, 1900004, 1.

[21] S. K. Lai, Y.-Y. Wang, J. Hanes, Adv. Drug Delivery Rev. 2009, 61, 158.

[22] M. Liu, J. Zhang, W. Shan, Y. Huang, Asian J. Pharm. Sci. 2014, 10, 275.

[23] Y. Y. Wang, S. K. Lai, J. S. Suk, A. Pace, R. Cone, J. Hanes, Angew. Chem., Int. Ed. 2008, 47, 9726.

[24] T. M. Ways, W. Lau, V. Khutoryanskiy, Polymer 2018, 10, 267.

[25] P. S. Pourshahab, K. Gilani, E. Moazeni, H. Eslahi, M. R. Fazeli, H. Jamalifar, J. Microencapsulation 2011, 28, 605.

[26] E. I. Rabea, M. E. . Badawy, C. V. Stevens, G. Smagghe, W. Steurbaut, Biomacromolecules 2003, 4, 1457.

[27] A. Machul, D. Mikołajczyk, A. Regiel-Futyra, P. B. Heczko, M. Strus, M. Arruebo, G. Stochel, A. Kyzioł, J. Biomater. Appl. 2015, 30, 269. 
836 [28] L. Liu, W. D. Yao, Y. F. Rao, X. Y. Lu, J. Q. Gao, Drug Delivery 2017, 24, 569.

837

838

839

840

841

842

843

844

845

846

847

848

849

850

851

852

853

854

855

856

857

858

859

860

861

862

863

864

865

866

867

868

869

870
[29] V. K. Nikam, K. B. Kotade, V. M. Gaware, R. T. Dolas, K. B. Dhamak, S. B. Somwanshi, A. N. Khadse, V. A. Kashid, Pharmacol. online 2011, 1, 152.

[30] A. K. Woischnig, L. M. Gonçalves, M. Ferreira, R. Kuehl, J. Kikhney, A. Moter, I. A. C. Ribeiro, A. J. Almeida, N. Khanna, A. F. Bettencourt, Int. J. Pharm. 2018, 550, 372.

[31] F. Ahmadi, Z. Oveisi, S. M. Samani, Z. Amoozgar, Res. Pharm. Sci. 2015, 10, 1.

[32] M. Mohammed, J. Syeda, K. Wasan, E. Wasan, Pharmaceutics 2017, 9, 53.

[33] A. Heydorn, A. T. Nielsen, M. Hentzer, C. Sternberg, M. Givskov, B. K. Ersbøll, S. Molin, Microbiology 2000, 146, 2395.

[34] K. Knop, R. Hoogenboom, D. Fischer, U. S. Schubert, Angew. Chem., Int. Ed. 2010, 49, 6288.

[35] Z. Sobhani, S. M. Samani, H. Montaseri, E. Khezri, Adv. Pharm. Bull. 2017, 7, 427.

[36] P. Shastri, R. Ubale, M. D’Souza, Drug Dev. Ind. Pharm. 2013, 39, 164.

[37] D. A. Gray, G. Dugar, P. Gamba, H. Strahl, M. J. Jonker, L. W. Hamoen, Nat. Commun. 2019, $10,1$.

[38] J. Du, H. M. Bandara, P. Du, H. Huang, K. Hoang, D. Nguyen, S. V. Mogarala, H. D. C. Smyth, Mol. Pharmaceutics 2015, 12, 1544.

[39] J. S. Suk, S. K. Lai, Y.-Y. Wang, L. M. Ensign, P. L. Zeitlin, M. P. Boyle, J. Hanes, Biomaterials 2009, 30, 2591.

[40] E. E. Mann, D. J. Wozniak, FEMS Microbiol. Rev. 2012, 36, 893.

[41] A. Brauner, O. Fridman, O. Gefen, N. Q. Balaban, Nat. Rev. Microbiol. 2016, 14, 320.

[42] K. Lewis, Nat. Rev. Microbiol. 2007, 5, 48.

[43] L. H. Nielsen, S. S. Keller, K. C. Gordon, A. Boisen, T. Rades, A. Müllertz, Eur. J. Pharm. Biopharm. 2012, 81, 418.

[44] L. H. Nielsen, S. S. Keller, A. Boisen, A. Müllertz, T. Rades, Drug Delivery Transl. Res. 2014, 4, 268.

[45] Z. Abid, C. Gundlach, O. Durucan, C. von Halling Laier, L. H. Nielsen, A. Boisen, S. S. Keller, Microelectron. Eng. 2017, 171, 20.

[46] B. W. Holloway, A. F. Morgan, Annu. Rev. Microbiol. 1986, 40, 79.

[47] M. Klausen, A. Heydorn, P. Ragas, L. Lambertsen, A. Aaes-Jørgensen, S. Molin, T. TolkerNielsen, Mol. Microbiol. 2003, 48, 1511.

[48] T. Tolker-Nielsen, C. Sternberg, Curr. Protoc. Microbiol. 2011, 21, 1B.2.1.

[49] M. Vorregaard, Comstat2 - A Modern 3D Image Analysis Environment for Biofilms, Technical University of Denmark, DTU, 2008. 


\section{WILEY-VCH}

871 Supporting Information

872

873 Microcontainer Delivery of Antibiotic Improves Treatment of Pseudomonas aeruginosa 874 Biofilms

875 Stine Egebro Birk*, Janus Anders Juul Haagensen, Helle Krogh Johansen, Søren Molin, Line Hagner

876 Nielsen and Anja Boisen

877
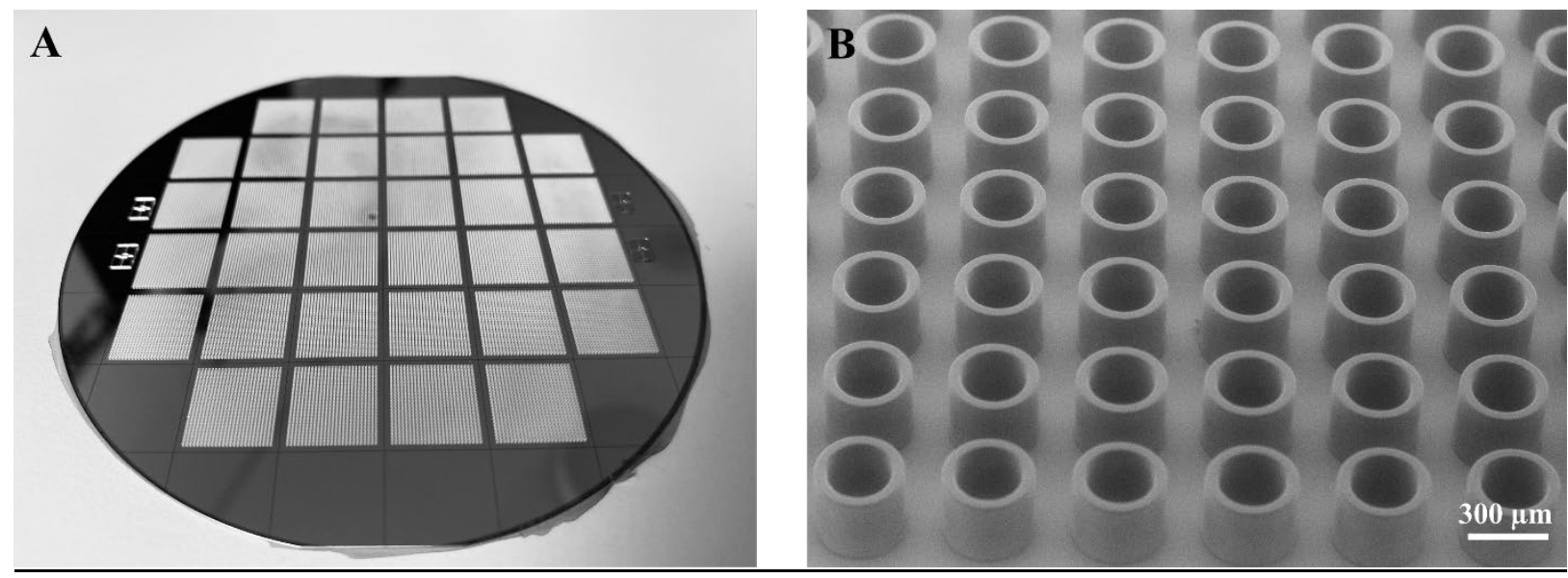

879 Figure S1. A) Photograph of a silicon wafer with 32 individual chips (12.8 x $12.8 \mathrm{~mm})$ each containing 625 SU-8 microcontainers. B) 880 Scanning electron microscopy (SEM) image of empty microcontainers on a chip. 
A

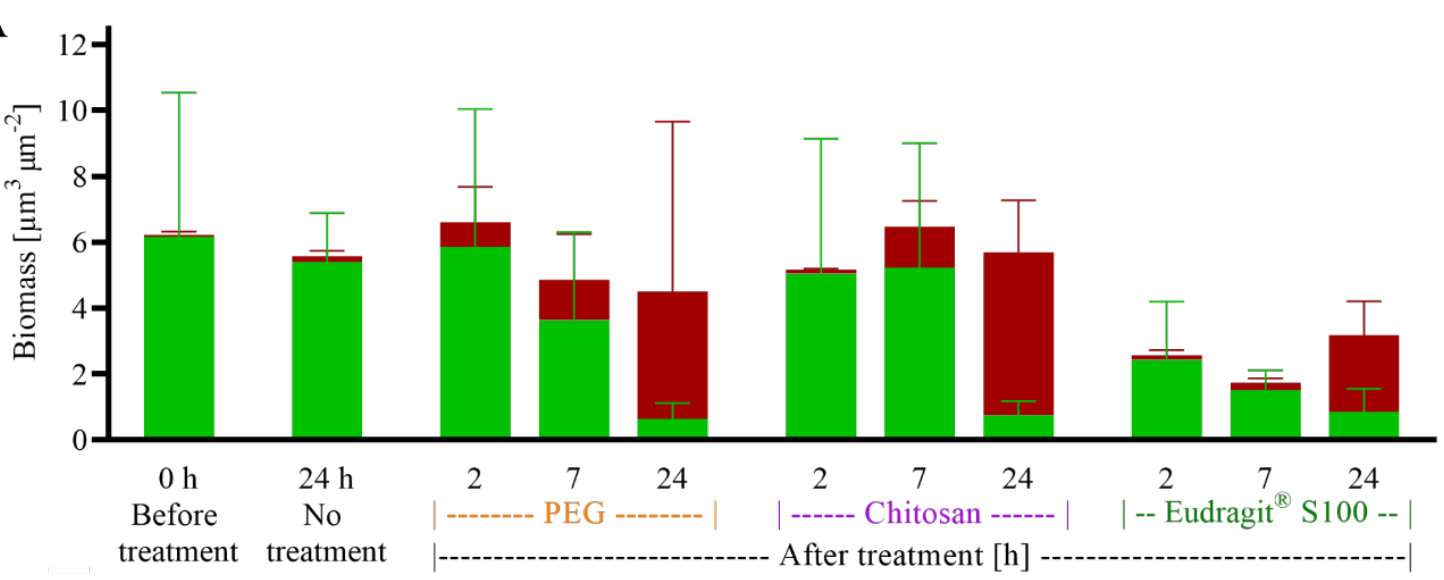

B

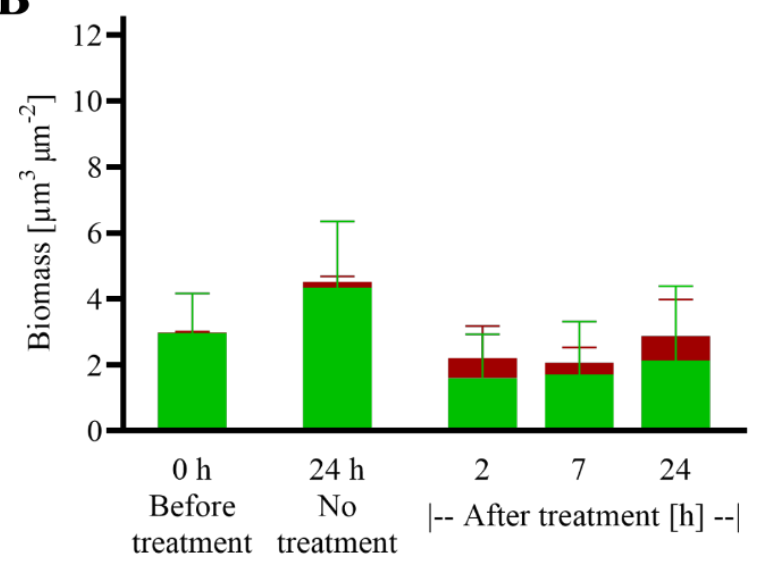

C

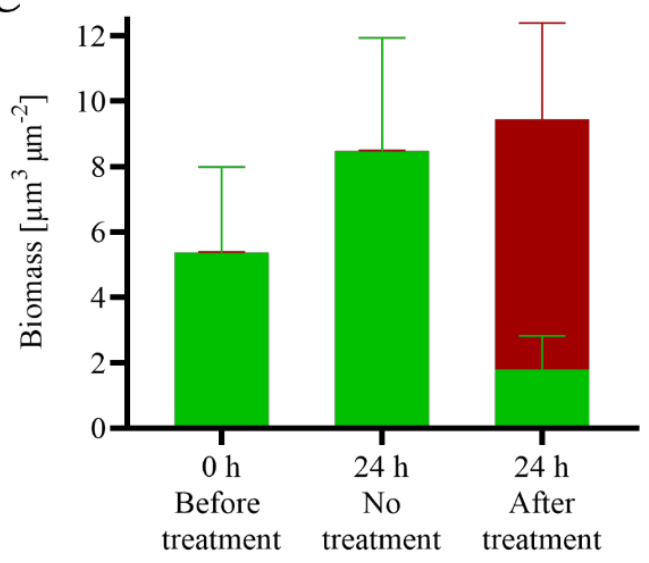

Figure S2. Graphs depicting the biomasses of PAO1 biofilm grown under flow for $96 \mathrm{~h}$ to a mature state and thereafter exposed to ciprofloxacin hydrochloride (CIP)-loaded microcontainers coated with either polyethylene glycol (PEG), chitosan or Eudragit ${ }^{\circledR}$ S100 (A) or a bolus dose of CIP (B) or constant perfusion of CIP (C). Green represents live bacteria. Red represents dead bacteria. Data are depicted as mean $+\mathrm{SD}(\mathrm{n}=4-24)$.

Table S1. The composition of modified FAB medium. A10 buffer, FB minimal medium with trace metals and the carbon source were autoclaved separately and mixed afterwards. Concentrations are given as final concentrations.

\begin{tabular}{llll}
\hline A10 buffer & \multicolumn{2}{l}{ FB minimal medium with trace metals } & Carbon source \\
\hline $33.7 \mathrm{mM} \mathrm{Na}_{2} \mathrm{HPO}_{4} \cdot 2 \mathrm{H}_{2} \mathrm{O}$ & $1 \mathrm{mM} \mathrm{MgCl}_{2}$ & $2 \mu \mathrm{g} \mathrm{L}^{-1} \mathrm{CuSO}_{4} \cdot 5 \mathrm{H}_{2} \mathrm{O}$ & $0.3 \mathrm{mM}$ glucose \\
$22.0 \mathrm{mM} \mathrm{KH}_{2} \mathrm{PO}_{4}$ & $0.1 \mathrm{mM} \mathrm{CaCl}_{2}$ & $2 \mu \mathrm{g} \mathrm{L}^{-1} \mathrm{ZnSO}_{4} \cdot 7 \mathrm{H}_{2} \mathrm{O}$ & \\
$15.1 \mathrm{mM}\left(\mathrm{NH}_{4}\right)_{2} \mathrm{SO}_{4}$ & $20 \mu \mathrm{g} \mathrm{L}^{-1} \mathrm{CaSO}_{4} \cdot 2 \mathrm{H}_{2} \mathrm{O}$ & $1 \mu \mathrm{g} \mathrm{L}^{-1} \mathrm{CoSO}_{4} \cdot 7 \mathrm{H}_{2} \mathrm{O}$ & \\
$51 \mathrm{mM} \mathrm{NaCl}$ & $20 \mu \mathrm{g} \mathrm{L}-1 \mathrm{FeSO}_{4} \cdot 7 \mathrm{H}_{2} \mathrm{O}$ & $1 \mu \mathrm{g} \mathrm{L}^{-1} \mathrm{NaMoO}_{4} \cdot \mathrm{H}_{2} \mathrm{O}$ & \\
& $2 \mu \mathrm{g} \mathrm{L}^{-1} \mathrm{MnSO}_{4} \cdot \mathrm{H}_{2} \mathrm{O}$ & $0.5 \mu \mathrm{g} \mathrm{L}^{-1} \mathrm{H}_{3} \mathrm{BO}_{3}$ & \\
& & & \\
&
\end{tabular}

